\title{
US IMMIGRATION POLICIES AND CITIZENSHIP ON THE SCREEN
}

\author{
Esther Álvarez López, University of Oviedo ${ }^{1}$ \\ Email: eal@uniovi.es
}

\begin{abstract}
Always a controversial issue, the US 'immigration problem' expresses anxieties over the nation's changing ethnic demographics, leading to the creation of exclusionary boundaries that are manifested in media prejudices and immigration rhetoric, controversial enforcement policies and questions about citizenship. Gregory Nava's Bordertown, Sergio Arau's A Day Without a Mexican, and Nickleodeon's Dora the Explorer critically address the immigration issue using an outlaw discourse that seeks to challenge the effects of a pervasive ideological anti-immigration rhetoric threatening to destroy an old national ethos.
\end{abstract}

Keywords: US immigration; citizenship; media; outlaw logics/discourse; NAFTA; Proposition 187; Arizona SB1070; Bordertown; A Day Without a Mexican; Dora the Explorer.

Título en español: "Políticas de inmigración y ciudadanía estadounidenses en pantalla"

Resumen: El 'problema de la inmigración' en Estados Unidos refleja miedos en torno a la cambiante demografía étnica de la nación que han llevado a la creación de líneas divisorias excluyentes, puestas de manifiesto en prejuicios y una retórica de la inmigración en los medios, en políticas controvertidas y en cuestiones relativas a la ciudadanía. Ciudad del Silencio, de Gregory Nava; Un día sin mexicanos, de Sergio Arau, y Dora la Exploradora examinan el tema de la inmigración, desafiando con su discurso 'outlaw' los efectos de una retórica ideológica anti-inmigrante que amenaza con destruir uno de los valores de la nación.

Palabras clave: Inmigración en Estados Unidos; ciudadanía; medios; lógica/discurso 'outlaw'; NAFTA; Proposición 187; Arizona SB1070; Ciudad del silencio; Un día sin mexicanos; Dora la Exploradora.

Boundary issues, David Sibley argues, are "characteristic of social and spatial relations" and therefore central to questions of exclusion (1995: 32). The 2,000-mile border that geographically separates the United States from Mexico has also become an important dividing metaphor that stands for the exclusionary boundaries that exist between US citizens and non-citizens, legal and illegal immigrants, self and other. Thus, in the current debates on US immigration policy, the border functions as "a dramatic prop" employed as a stage on which to project hopes, fears, and fantasies about the nation (Durand and Massey 2004: 1 ), as well as the nation's economic interests. ${ }^{2}$

\footnotetext{
1 Date of reception: 10 June 2013

Date of Acceptance: 10 October 2013

2 This essay is part of a research project (ref. FFI2010-17296) financed by the Ministry of Science and Innovation (MICINN).
} 
Today, as in the past, immigration in and to the US remains a contentious, vigorously debated topic that elicits a myriad of responses, ranging from the emotional and personal to the economic and political, from a population who is very ambiguous to this issue. Whereas a large majority is in favor of cutting down on immigration, Americans, white and colored alike, also know that they derive from immigrant stock themselves-excepting Native American people - ${ }^{3}$ hence the schizophrenic views that distil from their contradictory responses. This ambiguity is also reflected in the constant vacillations over legislation affecting immigrants, so that "periods marked by a massive influx of foreigners have traditionally been followed by an anti-immigration backlash" (Duignan and Gann 1998: 9). Mexican undocumented immigration, in particular, became "one of the salient political issues of the 1990s" (Maciel and García-Acevedo 1998: 149), and has continued to feature prominently in the twenty-first century, as verified during and after the 2004, 2008, and 2012 elections, when immigration surged onto the national agenda. Public concern rose in 2004, and by $200610 \%$ of Americans had named it the most important problem facing the nation (Brader, Valentino and Suhay 2008: 959). Indeed, the word 'problem' seems to have been unavoidably attached to 'immigration,' both legal and illegal. In various US Supreme Court cases (United States v. Valenzuela-Bernal, 1982; United States v. Cortez, 1981; United States v. Martinez-Fuerte, 1976), the Court showed their concern about the immigration issue, describing it as a "colossal problem" that posed "enormous difficulties" and "formidable law enforcement problems" (in Johnson 1997: 172). Saskia Sassen fittingly titled one of her articles on globalization "America's Immigration 'Problem"” (1989), in which she attempts to explain why US immigration policies have proven counterproductive so far.

Indisputably, we live in a media and information society, so the potentiality of newspapers, television, cinema, and most recently the Internet to influence the agenda of political debate and to mold public opinion should not be underestimated. They constitute an enormous source of "informal education and ideas" and, as such, "their content is never free of value judgments or individual biases" (Maciel and García-Acevedo 1998: 150). As could be expected, mass and printed media have paid considerable attention to what is now generally referred to as the 'illegal alien problem.' In the words and images they employ, in

\footnotetext{
President Barack Obama sparked the (ongoing) controversy over the origin of Native American people during a speech on immigration in Las Vegas on January 29, 2013, when he said to the nation, "unless you're one of the first Americans, Native Americans, you came from somewhere else-somebody brought you." (http:// indiancountrytodaymedianetwork.com/2013/01/30/obamas-native-american-reference-during-immigrationspeech-sparks-bering-strait-twitter) Radiocarbon dating has proved that people have been in the Americas for at least 11,500 years. Dr. David Reich, professor of genetics at Harvard, has recently conducted a research with a team of 60 experts that analyzed the genetic data of more than 500 individuals from 52 Native American and 17 Siberian groups looking for similarities and differences. They found that American Indians immigrated in three subsequent waves to North and South America from Asia via the Bering Strait land bridge, and that there is a good possibility that some American Indians are the direct descendants of Han-Chinese (http://indiancountrytodaymedianetwork.com/opinion/harvard-professor-confirms-bering-strait-theory-is-not-fact-126465). However, Reich also declared that the Bering Strait remains a theory, a hypothesis about history, but not a fact, and one he anticipates may be refuted with further research, although so far it is consistent with the data. Whereas most scholars accept the Bering Strait Land Bridge Theory, which in effect makes Native Americans migrant people coming from Asia, many Native people think that this hypothesis is invariably used to discredit notions of indigenous rights to landholding. The late Native American writer and scholar Vine Deloria Jr. openly rejected the Bering Strait theory and encouraged archeologists to put more consideration into American Indian creation stories.
} 
the (seldom positive) way they represent immigration they reveal their ideological prejudices. Kent A. Ono and John M. Sloop (2002) emphasize the role and importance of this 'rhetoric of immigration' in shaping social borders and constructing immigrant identities. What is at stake, they contend, "is the power to control what is represented publicly as dominant truths. Words and images populate the mediascape, and audiences' understanding of the politics of their communities . . . may be based on, among other things, how these representations appear" (2). Douglas Kellner argues in this respect that the media "are a profound and often misperceived source of cultural pedagogy: they contribute to educating us how to behave and what to think, feel, believe, fear, and desire -and what not to" (2011: 7): judgments, opinions and values are first created and then shaped according to the ideological constructs as well as the representations fabricated by the media, which have played a large part in the rise of xenophobia and the anti-immigrant or nativist sentiment sweeping across the nation. The images of immigrants as criminals, an invasion, un-American, and a burden on the welfare system that fill the media on a daily basis inevitably bring about anxieties, fear and hatred in the population, and further contribute to the exacerbation of racism in times of economic uncertainty, job insecurity and cultural apprehension.

Ono and Sloop critically reflect on this kind of rhetoric deployed by the media while they challenge the stereotypical constructions of immigration characteristic of the political discourse behind immigration propositions and laws through the lens of outlaw logics and discourse. Based on the belief that ordinary people, and not just dominant institutions, are participants in the construction of 'the public' outlaw logics are approaches to politics and social change that "encourage the formation of other ways of thinking about judgment and justice" (2002: 140) and are outside the logics of dominant discourse.

In what follows then, I will examine three of the most important US immigration policies of the past two decades (dominant discourse) as exemplified in specific media products from popular culture: a) The North American Free Trade Agreement (NAFTA, 1993 ) and its effects on Mexican migration, American economic interests and femicide, as shown in Bordertown (2006), ${ }^{4}$ by award-winning Gregory Nava; b) California's Proposition 187 (1994), satirized in A Day Without a Mexican (2004), by Sergio Arau; c) Arizona's SB 1070 (2010) and the anti-immigration backlash, as illustrated in the eponymous character of Nickleodeon cartoon Dora the Explorer, who has become the iconic symbol of the illegal immigrant crossing the border. The films conspicuously employ meta-media devices to create their outlaw discourse: In Bordertown, the female lead, Lauren Adrian (Jennifer Lopez), is a journalist from the Chicago Centinnel, and Alfonso Díaz (Antonio Banderas) directs the daily El Sol in Ciudad Juárez. The role of the press -Mexican and American- and their position in relation to the murders that assail the city is one of the issues tackled in the film. In A Day Without a Mexican, the protagonist, Lila (Yareli Arizmendi) is also a reporter and newscaster in a TV channel. The disappearance of all Latinos from California and its consequences are broadcast on a minute-by-minute basis as part of the news bulletin, with which the film actually opens. Meanwhile, Lila Rodriguez is put under constant surveillance at the hospital where she is treated after an accident to try to figure out why she has not disappeared

Released as Ciudad del silencio in Spain (February 2007). 
like the rest of Latinos.' Her case is then turned into a reality show for television and her eventual and surprising 'vanishing act' watched live by millions of viewers. As to Dora the Explorer, the cartoon child has become the unwitting subject of a myriad of Internet websites, blog posts, facebook messages, graphic art products, and news in national and international newpapers, which have drawn on, gravitated around, and together contributed to amplifying the immigration controversy at both a local and national level.

\section{NAFTA (1993) AND BORDERTOWN (2006)}

In 1993, the United States, Canada, and Mexico, created a trilateral trade block in North America: The North American Free Trade Agreement (NAFTA) came into force on January 1, 1994, holding out an alluring promise: President George H. W. Bush, Prime Minister Brian Mulroney, and President Carlos Salinas de Gortari, who had negotiated the terms of the agreement were confident that NAFTA would give such a boost to Mexican living standards that illegal immigration to the United States would drop (Canavagh et al. 2002: 62). Mexicans, the argument went, would benefit from the prosperity and employment that the agreement would generate through foreign investment, and not feel the need to cross the border. The deal would also support broader social goals, from creating good jobs to cleaning up the environment. Almost two decades later, the reality of globalization and free trade in the Mexican border regions has largely refuted these assumptions and provided sadder, less optimistic results, as working and living conditions have continually deteriorated since then. ${ }^{5}$

Foreign investment in Mexico has greatly impacted on the economic and labor structure of the country, uprooting people from traditional modes of existence, transforming farmers into migrant workers and potentially into emigrants (Sassen 1989: 821). The young protagonist's family in Nava's film is one of the thousands who have been affected by the introduction of new modes of production that have destroyed traditional ways of earning a living. When their lands are taken away by the government, Eva Jiménez's father leaves for the US in search of work, whereas the mother and siblings head for the border city of Juárez: "Así que nos dijeron, id a la frontera, trabajad en las maquiladoras, ganaréis dinero." However, the rosy prospects of the government were blatantly contradicted by the reality of Juárez and the global economic system represented by the maquiladoras: "El gobierno y las fábricas se lo quedan todo; el dinero es para ellos. Para nosotros, nada" (Nava 2006). Without money, without lands, they cannot return to their places of origin and are condemned to slave away for a meager salary that barely enables their survival.

The expansion of transnational corporate power through the proliferation of thousands of export-oriented manufacturing plants (popularly known as maquilas) and Mexico's

\footnotetext{
$5 \quad$ Although after the implementation of NAFTA 1.2 million jobs were created in Mexico, wages are now lower than in the year NAFTA began (Canavagh et al. 2002: 62). Besides, the share of Mexicans living in poverty has risen; existing labor laws are not enforced; protection of workers is inexistent and exploitation is rampant. According to the Comité Fronterizo de Obreras (CFO), NAFTA has caused "a sharp drop in the standard of living; a marked intensification of the labor process through speed-ups and other tactics, and a sustained campaign to undermine unions, labor rights and social protections" (in Arriola 2010: 32). With these indicators, it is no wonder that Juarez is portrayed as Mexico's symbol of the failed promises of free trade (2010: 26) and globalization.
} 
suspension of 'territorial closure' in response to the demands of foreign capital, the United States and other global actors have ultimately been responsible for the creation of "disposable non-citizens" (Schmidt Camacho 2005) "whose value to the international system derives from their lack of access to rights" (Jean Franco, qtd. in Schmidt Camacho 2005, 258). As a result of NAFTA, in Ciudad Juárez subaltern women are the unfortunate victims of the detachment of citizenship from the nation-state, a kind of "denationalized citizenship" whose destabilizing dynamics, contrary to what Saskia Sassen contends, are not "producing operational and rhetorical openings for the emergence of new types of political subjects and new spatialities for politics" (2002: 5), but the encounter with new forms of social violence and repression at the hands of both state and non-state actors. While international observers represent the gender violence in Juárez as a regressive cultural manifestation of masculine aggression, Schmidt Camacho claims that it is rather the outcome of the government's denationalization of poor women's citizenship $(2005,267)$, which is itself produced "through state failure and state violence": "the impunity of violent crime," she argues, "necessarily devalues both citizenship and citizens" (256).

Although figures vary, it is estimated that almost five hundred women have been murdered to date and thousands more have disappeared since 1993. Despite the death toll, there has been no serious or thorough investigation on the part of the authorities, who have tended to blame the victims for their tragic fate. Many believe that, regardless of the actual perpetrators of the crimes, the Juárez femicides are the responsibility of NAFTA and of the gendered system of production that sustains it, which constructs working women as cheap labor, dispensable and disposable, commodifies their bodies and suppresses their rights (Livingston 2004; Gaspar de Alba 2005 2010; Schmidt Camacho 2005; Arriola 2010).

Borderdown (2006) is Gregory Nava's (El Norte, 1983; My Family/Mi familia, 1995) contribution to denounce these femicides, an attempt to break the silence and secrecy that surrounds them by calling attention to systemic abuse and sexual violence. Rupert Knox, a researcher on Mexico for Amnesty International, hopes this fictional representation of facts "will enable real change" (Gerson 2007). Drawing on interviews Nava made and the stories told by family members of the murdered young women, the Californian director created this thriller-drama, which took him an eight-year journey to get made. The valuable firsthand information he gathered in Juárez led Nava to surmise that NAFTA and the corporate businesses that have flourished with free trade are fully accountable for the killings that have been assailing this northern Mexican city for two decades now. His film is mainly addressed to American and international audiences that for the most part are completely ignorant of the murders on the other side of the Mexican-US border, owing partly to the lack of interest of the press and the media in general. ${ }^{6}$ In particular, he targets American people in their comfort zone, whose leisure and everyday lives depend largely on the commodities -TV sets, computers, technological and household appliances, even clothes, etc.- mass-produced at the maquiladoras by these women, some of whom end up brutally murdered in the empty desert lots and other parts of the city's geography.

\footnotetext{
6 "The snippets of fact that once in a great while percolate up through the Mexican press are ignored by the U.S. government and its citizens," says Charles Bowden (1996) about the United States' lack of interest in the tragedy that has been going on in Ciudad Juárez for twenty years.
} 
In order to fill in the gap of information about this economic system that neither the press nor the institutions are willing to provide, the film opens with a text that brings to the fore the free trade agreement, maquiladoras and their exploitation of migrant women's labor: "Taking advantage of cheap labor and no tariffs, these companies manufacture goods at low cost to be sold in the United States. . . . The 'maquiladoras' hire mainly young women because they work for lower wages and complain less about the long hours and harsh working conditions" (Nava 2006). Later on Nava will illustrate NAFTA's impact on these young workers with images, both inside and outside the factories, in the city, in the poverty-ridden colonias and in the desert where the bodies of the women are found, that vividly underpin these words. The film's development and denouement clearly expose the connivance of Mexican and American corporate interests in this femicide.

This is Nava's contention in Bordertown. From all the popular theories about the who and why of the murders -serial killers, satanic cults, snuff films, organ harvesting, white slavery, cartel killing, the doings of Sharif Abdel Latif Sharif or of Los Rebeldes, a local gang, or the corrupt Mexican police, among others (Gaspar de Alba 2010: 67)-, in the film he points a finger at NAFTA's responsibility in these rapes, ${ }^{7}$ killings, and disappearances by bringing together a real 1999 case and the arrest of the criminals-six bus drivers, collectively known as Los Choferes-with Nava's theory of the involvement of the Mexican and American accomplices, among them politicians, businessmen and factory owners: In 1999, a 14-year old girl miraculously survived a brutal attack, then literally unburied herself from her grave in the desert, and eventually identified the driver of one of the companies' buses that take workers to and from the maquilas as her rapist. As a result of her testimony, authorities arrested the band of Los Choferes and charged them with the slaying of seven women. Eva Jiménez (Maya Zapata), the 16-year-old protagonist of Bordertown, could well be this real-life survivor, with whom she shares not only the gross details of her rape and attempted murder, but also a rural background (Oaxaca in one case, Durango in the other), a history of dispossession and displacement and a life marked by poverty and exclusion.

Rather than seek help in the judicial system or the police, who, as Nava clearly shows throughout this film, are at the service of the powerful corporations and determined to keep crimes covered up and unresolved, Eva and her mother find in the press a convenient loudspeaker to voice their plight. In the film, they resort to the local newspaper El Sol and its director, Alfonso Díaz, who is well known among the victims' families for his active commitment in trying to find out the truth behind the killings. The film's first shots focus on the devastation reigning in the city's shantytowns, where the insalubrious living conditions, among the debris and toxic waste of industry, turn the life of their dwellers into a protracted death, while a car drives around the streets of Juárez reporting the killings of more women on a loudspeaker: "Más asesinatos en Juárez," "Se han encontrado tres

Chicana feminists and scholars (see Schmidt Camacho 2005; Livingston 2004; Arriola 2010; Gaspar de Alba 2005, 2010) contend that the rapid industrialization produced by Mexico's intense participation in the (global) economy which NAFTA affords has further fueled the (local) systematic violence committed against women in Juárez as a result of cultural shifts and structural changes in the social and political realms of the city. Likewise, in Desert Blood. The Juárez Murders (2005), Alicia Gaspar de Alba holds this border economic order largely responsible for the existing culture of sexual violence that objectifies and commodifies women by transforming them into disposable merchandise. 
cadáveres de mujeres," "Encuentre la verdad en El Sol," "El Sol dice la verdad." In a city built on silence and lies, the truth voiced by Díaz's newspaper is dangerous (and rare) news. Soon after, the police violently confiscate the papers in an attempt to keep these murders as buried from public view as the victims' bodies are in their desert graves. Díaz's outlaw discourse and his determination to delve into the killings and disappearances in spite of institutional opposition are a problem for the Mexican authorities, as he exposes dominant discourse and those who represent it to be sham. As a result, he is constantly harassed-and eventually killed-by the police and other powerful political and economic actors in Juárez whose interests in the city and business revenues are threatened by his investigations.

Lauren Adrian, an ambitious American journalist of The Chicago Centinel sent by her editor (Martin Sheen) to Juárez to write a report on the murders, will help Eva to find and identify the perpetrators of her attack, putting her own life at risk. Though initially skeptical about the femicides, in her investigations Adrian manages to gather ample evidence that negates the arguments sustained by dominant discourse. Eva's recognition of one of her attackers in a party at the Salamancas' house, a prominent Juárez family, provides the reporter with the lead she needs to disclose a scheme among bus drivers and men of high standing to abduct, rape, and murder young maquiladora workers. The party brings together representatives of private enterprises, as well as political, economic and religious institutions: an American Senator, Japanese and American factory presidents, a Mexican governor, even an archbishop, chat and laugh casually on the luxury gardens of the Salamancas' estate, oblivious to the brutal reality that is killing Ciudad Juárez. Like Díaz in El Sol, in Bordertown Nava positions himself with the victims, and challenging dominant discourse, he unmasks the real perpetrators of the crimes: with their silence and connivance, both Mexican and American power structures contribute to the perpetuation of the murders. As Adrian explains to George Morgan, her editor,

The screams of the women of Juárez are silent because no one will listen. Not the giant corporations who make their profit from the labor of these women; not the governments of Mexico and the United States who benefit from the free trade agreements. No one will listen. All the evidence point to the fact that there are many killers. A whole culture of murder that just gets worse and worse the more it's denied and covered up. You see, covering it up is less expensive than protecting the women. (Nava 2006)

The American Senator who had been at the Salamancas' party, together with presidents of national press associations, easily persuade Morgan against printing Adrian's article about Juárez on the grounds that it would jeopardize American interests, thus silencing the press as well, which is transformed thereby into yet another willing accomplice of the murders. ${ }^{8}$ While the US Congress has passed bills to expand free trade agreements to include Central America [CAFTA], although no dispositions to protect the workers have been implemented as yet, the murder of the brown and poor women of Juárez continues.

\footnotetext{
8 The film was not released on the big screen in the US, a fact that further contributes to underscore Nava's message regarding the silence that surrounds the Juárez murders and NAFTA, the very powerful American interests behind this free trade agreement and the convenience to keep this information from the American public.
} 
PROPOSITION 187 (1994) AND A DAY WITHOUT A MEXICAN (2004)

The year of NAFTA's implementation was also the year Californians voted Proposition 187, also known as Save Our State initiative (SOS from 'illegal aliens,' 1994), developed by a coalition of nativist Californians together with anti-immigration governor Peter Wilson. With it, they wanted to 'send a message' to Washington about the illegal immigration 'problem' that some believed was assailing California primarily, but also other Southwestern states, such as Texas or New Mexico. In all of these states the racial demographics of immigration-with a Mexican and Latino population growing at a fast pace-was turning these US territories into, in the expression of American conservative commentator and politician Pat Buchanan, "Third World states" (2006). ${ }^{9}$ Nativists resented the fact that in a few decades whites would presumably be reduced to a minority overgrown by Mexicans and OTMs ('other than Mexicans,' those coming from Latin America, Middle East, Africa, and Asia), a fact that greatly contributed to heightening societal anxiety and helped fuel the calls for the restriction (Johnson 1997: 177). Proponents of the proposition thus called for boundaries, both spatial and moral, using a rhetoric that focused "on the familiarity versus the strangeness of others, good and bad people" (Ono and Sloop 2002: 66), boundaries that would keep the malaise of immigrant 'infestation' away from US territory.

Through greater measures of enforcement, they thought they would be able to maintain the economic and ideological unity of the nation safe from these subaltern bodies struggling over citizenship and subjectivity. Marcelo Suárez-Orozco claims that Proposition 187 is a paradigm of the contradictions engendered by new postnational social formations. On the one hand, postindustrial democracies in the western hemisphere have developed what he calls "an addiction" (1996: 151) to recruit and exploit foreign inexpensive labor to do the dangerous, dirty, and demanding jobs. On the other hand, "new immigrants have become the focus of powerful anxieties" that have very much to do with economic stagnation at home, the failings of the welfare state and local psychocultural angsts "in the face of increasingly powerful transnational formations" (1996: 151). These fears were finally manifested in restrictionism sentiment, immigrant scapegoating and new politics toward immigration.

Anti-immigration discourse leading to Proposition 187 refers to undocumented immigrants in demeaning terms, and portrays them basically as parasite welfare recipients who deplete California's social welfare budget, taking more out of the economic system than they are returning-a statement that, incidentally, is not supported by the figures. The SOS initiative attempted to ban illegal immigrants from government-funded services, such as health welfare, prenatal care, social services or public schooling, and required local officials to report those suspected of being in the country without papers to state and federal authorities. The ideological conservative assault on the public sector through a deficit-mania and balanced-budget conservatism -deliberately constructed and self-consciously exploitedresults in frustration and anger, and ultimately in restrictionism sentiment among taxpayers facing economic uncertainty, at the same time that such policy "deflects responsibility from

\footnotetext{
$9 \quad$ Patrick Buchanan published a book entitled State of Emergency: The Third World Invasion and Conquest of America in 2007.
} 
the private sector's cost-cutting, and facilitates the austerity measures of the government as it dismantles the safety net" (Calavita 1996: 295).

Three years after the voting of California's Proposition 187 and the subsequent implementation of Operation Gatekeeper in $1994,{ }^{10}$ Sergio Arau presented his short A Day Without a Mexican in documentary fashion (1997), later expanded into a film (2004). This Latino mockumentary ends with the scriptwriters' (Arau and Arizmendi) acknowledgment to Pete Wilson "who forced and inspired us to create this program." A Day Without a Mexican examines in a satirical vein the disastrous consequences that supervene the day Mexicans and other people of Latino origin suddenly and mysteriously disappear from the State of California. The film follows up, and aims to be a response to, the widespread public discussion around immigration that dominated California's social and political scene in the 1990s. It is also a sci-fi critical enactment of the immigration policies that were enforced as a consequence of those debates, which are exemplified by means of interviews to an array of Californian citizens conveniently interspersed throughout the film. From a UCLA professor to a Hollywood actress, from a politician to a plastic surgeon's wife, from a school teacher to Border Patrol officers, people offer their views on the pro- or anti-immigration issue that divides families like the McClaires, a father and a son on opposite ends of the controversy, as has divided Californians and the national family as well. Arau reveals in the film how the rhetoric of Proposition 187 offered a particularly important instance of what Pat Buchanan (2004) defined as "the deepest, most divisive issues of our time: ethnicity, nation, culture." Indeed, this legislative initiative tackled many of the concerns Americans confront in times of severe economic crises, concerns which ultimately revolve around ideographs such as nation, citizenship, and, linking them both, immigration (see Ono and Sloop 2002: 28). ${ }^{11}$

A Day Without a Mexican articulates an outlaw discourse that seeks to expose, undermine and change the rationale behind the assumptions of a fundamentally racist political discourse. Although immigration restrictionists in the United States have increasingly focused on an economic and cultural argument, downplaying the role of race, ${ }^{12}$ the campaign and the Proposition itself demonstrated that economic considerations were not the sole motivation

10 Boundary enforcement strategy began on October 1, 1994, to reduce unauthorized migrant crossings of the US-Mexico boundary into southern California. In the words of the Border Patrol, it is a "territorial denial" or "prevention through deterrence" strategy that attempts to thwart migrants from entering the US (as opposed to the old strategy of apprehending migrants after they cross) through the forward deployment of Border Patrol agents and increased use of surveillance technologies and support infrastructure (Nevins 2012: 2).

11 In Geographies of Exclusion. Society and Difference in the West, David Sibley observes that "at the social level, as at the individual level, an awareness of group boundaries can be expressed in the opposition between purity and defilement" (1995: 36), and that "spatial boundaries are in part moral boundaries" (39). Seen in this light, Proposition 187 and Operation Gatekeeper can be said to have promoted a boundary enforcement strategy at all levels in order to stop the waves of illegal immigrants from crossing the border and 'infesting' California and other US states; thus, this measure would help preserve the (moral) 'purity' as well as the economic and ideological unity of the nation against the 'defilement' of immigrants, to use Sibley's terms.

12 In his classic "The Theory of Cultural Racism" (1992), James M. Blaut contends that racist theory and practice have to recourse to cultural and intellectual history, rather than to biology or religious-based theories of racial inferiority or superiority, to prove the superiority of Europeans, read (white) Americans in this context. The cultural racism argument, then, asserts that marginalized people or groups have proven unable (or unwilling) to realize their capacity because of their inferior culture, lesser abilities, or because they have not learned to realize their capacities, "the things one needs to be treated as an equal," "how to think rationally" or "how to behave in appropriate ways." 
for the initiative, as drafters often expressed plainly nativist sentiments and never failed to refer to the race of the immigrant 'invaders.' Thus, the rhetoric of Proposition 187 "not only constructs the immigrant subject but also constructs the immigrant subject as racialized in particular ways" (Ono and Sloop 2002: 28).

In A Day Without a Mexican, Sergio Arau cleverly destabilizes the concept of 'race' through the character of Lila Rodriguez, also known by the Anglicized version of her name, Lyla Rod, who is supposedly of Mexican descent but surprisingly does not disappear like the rest of Latinos. ${ }^{13}$ She later on finds out that she is actually an Armenian adopted by Mexicans, which explains why she has not followed the same fate as them. She vanishes, though, the moment she realizes that, despite her assimilation and attempts to 'pass' in order to succeed in her career, her heart, her beloved ones and her most cherished memories make her inevitably a Mexican, if not by descent at least by consent. In Beyond Ethnicity: Consent and Descent in American Culture (1986), Werner Sollors focuses on the tensions between consent and descent relations, which are at the core of American ethnicity and culture. Following anthropologists, Sollors defines descent relations as those characterized by substance, i.e., blood or nature, whereas consent relations describe those of law or marriage. Thus, descent language "emphasizes our positions as heirs, our hereditary qualities, liabilities, and entitlements; consent language stresses our abilities as mature free agents and 'architects of our fates' to choose our spouses, our destinies, and our political systems" (1986: 6).

Arau keeps marriage out of Lila Rodriguez's affiliations and emphasizes the idea of her agency to decide freely instead. In the end, Lila voluntarily chooses to be Mexican because her emotional bonds to the family and culture she has grown up in prove to be stronger than any imperatives established by law, birth or blood. In this sense, she illustrates the postethnic perspective defended by David A. Hollinger, which "favors voluntary over involuntary affiliations ... and promotes solidarities of wide scope that incorporate people with different ethnic and racial backgrounds" (2000: 2). A postethnic perspective, according to Hollinger, builds upon cosmopolitanism rather than pluralism, as the former "is more wary of traditional enclosures ... promotes multiple identities, emphasizes the dynamic and changing character of many groups, and is responsive to the potential for creating new cultural combinations" (2000: 3-4). With Lila's case, Arau seems to endorse this postethnic frame at the same time that he underscores the fact that the identities people assume are acquired largely through (chosen versus prescribed) affiliations, which suggest flexibility and performativity rather than fixity and givenness.

Hollinger ascribes the latter characteristics to identity, and they may well apply to nativists' ideas about 'American' self-fashioned identity and self-image. Thus, nativists oppose socio-cultural difference and reject internal minorities because they allegedly threaten the American way of life. Nativists, thus, would follow an ethnocentrist perspective that holds that whiteness equals power and sameness, as well as a fixed, exclusivist national identity: "We were one nation, one people. We worshipped the same God, spoke the same English language, studied American history and English literature, honored the same heroes, read

\footnotetext{
13 Yareli Arizmendi was born in Mexico and raised in the United States. She coined the word AmeXican to describe herself.
} 
the same books, watched the same TV shows, went to the same movies, and saw ourselves as defenders of Western Civilization against the godless communism of the Soviet Empire" (Buchanan 2004). The new enemies in contemporary society, the new others, have ostensibly shifted and now communists have been replaced by internal minorities, documented and/or undocumented: because of the difficulty in telling a legal from an illegal alien, a Mexican from a Chicano, or a Chicano from other Latinos, "the media environment in effect helps create a situation in which all Mexican-descent peoples are under suspicion as 'other' (Ono and Sloop 2002: 37).

A Day Without a Mexican evinces an outlaw discourse that challenges popular/ized and racial/ized stereotypical depictions of Mexican and other Latino immigrants, who are all lumped together in the American imaginary regardless of their places of origin: "They're illegal Mexicans from Guatemala and Honduras," someone says in the film, while on a freeze-frame the caption "Guatemalans and Hondurans are not Mexican" is typewritten letter by letter on the screen, a technique that has the effect of increasing the subversive political significance and satirical potential of the message. Likewise, the filmmaker effectively undercuts the proclivity of mainstream society to ascribe an array of prejudiced traitsphysical, psychological, intellectual, etc.-to Mexicans/Latinos/Hispanics. When actress Crystal Lucci finds out that her childhood friend Gabriela has disappeared, she remarks, "Does she have to go? Well, she's Latino, but you can barely tell that she has an accent at all, and she has beautiful green eyes. No, no, Gabriela is normal. She's normal, she's just like me. I mean, there's no way Gabriela... and besides, I mean, Gabriela is a doctor!" (Arau 2004). The association Mexican-alien/different/Other, or Mexican-immigrant/unskilled worker is pervasive in the collective unconscious. The film seeks to destroy these biased notions by dedicating a whole part of it to the--mostly unknown-"Contributions" of notable Latinos: attorneys such as Dan Gonzalez, who got key evidence for the O.J. Simpson trial; scientists as Ralph Gonzalez and Mario Molina; famous artists such as American-SurinamPuerto Rican actor Jimmy Smits, Mexican-American Edward James Olmos, or even Spanish opera singer Placido Domingo; popular sportsmen and teams, etc. are only a few in the ranks of Latinos who have contributed to both the advancement and entertainment of the world community.

In spite of these examples of achievement and fame, the film focuses to a large extent on the average Mexican/Latino individual, the typical José commodified as low-wage labor in and by California's economic system. The filmmaker overtly criticizes Americans' perception of Latino immigrants as solely human capital, "represented in terms of economic value, connected to their position within the system of capital rather than, for instance, to their right to be seen and treated as members of a social community" (Ono and Sloop 2002: 32). It is precisely their alleged insignificance and absolute social invisibility, their lack of rights to be fully seen in spite of their invaluable contribution to the State of California that the film foregrounds and seeks to subvert. A day without Mexicans would indeed be a day just a step before apocalypse for the seventh largest economy in the world.

The film also dismantles the figures that charge immigrants with being an economic burden and counters these numbers by providing evidence of Latinos' instrumental contribution in sustaining California's economy and whole social system. Without them, the film claims, the Sunshine State, now enveloped in a thick fog, would inevitably collapse. 
Abdul Hassan, a character featuring a UCLA Professor at the School of Public Policy, vehemently declares, "This is a disaster. You're waiting for the Big One, this is it! The core of the economy is gone; it's what we told people was gonna happen. These are the people that have been sustaining the economy!" (Arau 2004). The disappearance of thirteen million Latinos, one third of California's population, workers but also consumers and taxpayers, soon threatens to bring about an economic catastrophe of unpredictable proportions. The effects are mostly noticeable in the Central Valley, where fruits and vegetables are rotting in the fields-with the resultant rise in prices at grocery stores and the emergence of a black market where tomatoes are sold at astronomic prices by former drug dealers. Meanwhile, restaurants, schools, factories, businesses big and small are forced to shut down for lack of personnel but also of (Latino) customers and users.

Besides having dramatic consequences in the economy and in the social sphere, the absence of all these Latinas/os also affects personal lives, as separations involve husbands and wives, siblings, friends, lovers, etc., not to mention how their disappearance upsets the lifestyle of the millions of people whose everyday routine turns into chaos at home as they are left to fend for themselves: they must now look after their children, do the household chores, cook, and numerous other indispensable tasks that Latino immigrants, documented and undocumented alike, had always done for them but gone unappreciated. The situation grows to be so complex and challenging that even Steven Abercrombie, a conservative California State Senator who had advocated Proposition 187, and Border Patrol officers Kennedy and Carr, about to lose their jobs due to lack of activity on the border, grieve and beg Mexicans to "please, come back, amigos. We're sorry. Yeah, we're sorry," "Please, come back, por favor."

The majority of the provisions of Proposition 187 were temporarily barred enforcement and the whole measure itself eventually overturned in court, but it contributed to reshape the nation's immigration debate, with movements forming in other states to push through similar propositions, as was the case of Arizona's SB 1070.

\section{ARIZONA SB 1070 (2010) AND DORA THE EXPLORER (2000-)}

On April 23, 2010, Arizona Governor Jan Brewer signed SB 1070, which she said would help combat illegal immigration. US toughest bill on illegal immigration, SB 1070 was a controversial law welcomed by many American citizens and several states, but considered by others to be a violation of human rights, a recipe for racial and ethnic profiling and an open invitation for harassment and discrimination against Latinos regardless of their citizenship status. The law requires authorities to question people about their immigration status if, during the course of their duties, said authorities have reason to suspect that these people are in the country unlawfully. ${ }^{14}$ SB 1070 was modified on April 30, 2010 with the enactment of House Bill (HB) 2162, "which changed the language such that police officers would only be required to check the immigration status of people during a lawful stop, detention, or arrest” (Golash-Boza 2012: 42). However, determining a person's legal

\footnotetext{
14 For a critical analysis of Arizona's SB 1070, see Tanya Maria Golash-Boza's Immigration Nation. Raids,
} Detentions, and Deportations in Post-9/11 America (Boulder, London: Paradigm, 2012). 
status and establishing whether s/he is lawfully or unlawfully present in the US is a legal distinction that may not be discernible to a law enforcement official (42). This and other legal problems that affected SB 1070 led Judge Susan Bolton to issue a preliminary injunction against sections of the law that blocked several of the provisions and requirements on the very day it was scheduled to take effect. However, as Tanya Golash-Boza contends, "the rhetoric on which it was based lives on-especially the idea that all undocumented migrants are criminals" (2012: 43)

A Latina cartoon character in a twenty-three minute television program for preschoolerspremiered on Nick Jr., a Nickleodeon children's television network, in 2000-has amazingly been caught up in the Arizona immigration debate and become a popular symbol of the illegal border-crosser. Dora the Explorer, an adventurous and bilingual seven-year old girl who teaches English/Spanish to children all over the world, has crossed the border between fiction and reality and acquired a political life of her own beyond her virtual existence. Although she has uncertain origins, she looks to be from 'south of the border,' which is the reason why her life and legal status have been under scrutiny since the passing of the Arizona law. Despite the insistence of some viewers who earnestly demanded to know about her origins and even made an issue of it, Nickleodeon has repeatedly refused to give any clues as to her ethnic and national background or her citizen status. Angharad Valdivia, who teaches media studies at the University of Illinois and has explored this issue, comments that Dora has always been "ambiguously constructed": "In the US, the way we understand race is about putting people in categories, and we're uncomfortable with people we can't put in categories" (Fisher 2010). Dan Martinsen, executive vice president of communications for the company, has attempted to close the case of Dora's birthplace by simply describing her as "pan-Latina." In a similar vein, Nicole M. Guidotti-Hernández contends that Dora, a transnational figure, "marks how Latinidad is used to create meaning on a global scale" (2007: 213).

Erynn Masi de Casanova, Professor of Sociology at the University of Cincinnati, has explained why the child has become a social phenomenon far beyond the realm of her television existence. She argues that Dora serves as an empty screen on which people can project their thoughts and feelings about Latinos; they feel that they can say negative things because it is just a cartoon character (Fisher 2010). True to what de Casanova argues, from the inception of the show, parents began posting messages on the Dora the Explorer Nick Jr. website to "express political anxiety about language, immigration, citizenship, entertainment, and education" (Guidotti-Hernández 2007: 211). Parents' dialogues showed these concerns, evincing how Dora had become a site of a heated debate regarding Latino/a subjectivity and citizenship.

Before 2010, Dora's actions were marked by mobility, as she moved "through space uninhibited and unpoliced; her brown body . . . not criminalized as are the majority of Latinos we see on television in this post-9/11 period of racial profiling" (Guidotti-Hernández 2007: 218). In 2010, however, Dora's image began to vividly and dramatically symbolize the plight of ethnic documented US citizens, but most especially of a specific underclass of undocumented immigrants of Latino descent, in a country where the nativist, anti-immigrant sentiment is gaining ground. In a contest called "Is Dora the Explorer an Illegal Immigrant?", where participants were asked to Photoshop what Dora's life would be like if she were an 
illegal immigrant in Arizona, Debbie Groben, of Sarasota, Fla., came up with an image that illustrates better than any other the anti-immigrant madness. The child appears with a black eye, battered lip and bloody nose in a police photograph accused of 'illegal border crossing' and 'resisting arrest' after her capture by immigration authorities.

On the wake of the signing of the Arizona law, various websites and numerous bloggers entered the debates, posting multifarious opinions for and against the law, for and against Dora, in messages that expressed their anxieties about immigration or about the law. In "Is Dora the Explorer being used in the Arizona immigration debate?" (2010) Teresa Puente comments on Dora's mugshot picture and exclaims, "Poor, poor Dora, I thought. Then I started laughing hysterically. I think it's a funny use of the image making a point about how absurd the new immigration law is in Arizona": although she is an explorer, she probably does not carry a passport or birth certificate, a fact that makes her "ripe for racially profiling [if stopped by police] under this new Arizona immigration law." As many other people who expressed their concern for the reaction of children who might see Dora being abused by the police and the object of furious racist attacks, Teresa Puente also ruminates about how she would explain to her five-year-old nephew what happened to Dora if he saw her booking photo. With a kind of illogical, but full of common sense, outlaw discourse that considers Dora as real, she finally declares, "She's a child so it's not her fault if she is undocumented. We shouldn't blame Dora."

Likewise, in an article published online in the Huffington Post on May 4, 2010, screenwriter, playwright, and lyricist Sherman Yellen gives a scathing account of this image that depicts 'undocumented' Dora's 'arrest' in Phoenix. According to his 'report,' the young girl, together with her cousin Diego and her pet monkey Boots were "rounded up in a raid of an Hispanic neighborhood preparing for Cinco de Mayo festivities. ${ }^{15}$ Her famous talking backpack, which the Sheriff in charge of the detention described as "sophisticated electronic devices designed to outwit our border police," was duly confiscated and examined by the FBI. As Yellen and Puente, other people used an outlaw discourse in an attempt to (satirically) counter the morally unacceptable anti-immigrant madness and xenophobia that were taking root in Arizona.

Always a controversial issue, the US 'immigration problem' has usually found a way onto the screen to reflect the challenges that it has posed for immigrants and citizens alike. Debates over immigration flows, immigrant incorporation and citizenship have taken up the social and political life of the nation with a new surge in the contemporary context. Anxieties over the nation's changing ethnic demographics, characterized in the popular press as "the browning of America" (Demo 2004: 216), together with domestic economic, political and institutional factors have provoked varied responses, including immigration enforcement efforts such as Proposition 187 or Arizona SB1070. Nava's Bordertown, Arau's A Day Without a Mexican and Nickleodeon's Dora the Explorer have crossed real and virtual media boundaries to critically address the immigration issue from an outlaw logic

\footnotetext{
15 Cinco de Mayo originated with Mexican-American communities in the American West as a way to commemorate the anniversary of the Mexican army's 1862 victory over France at the Battle of Puebla during the Franco-Mexican War. Today the date is observed in the US as a celebration of Mexican culture, heritage and pride, particularly in areas with large Mexican-American populations.
} 
that seeks to challenge as well as reverse the effects of a potent and pervasive ideological anti-immigration rhetoric that is threatening to destroy an old national ethos.

\section{REFERENCES}

Arau, S. 2004. A Day Without a Mexican. Televisa Cine.

ArriolA, E.R. 2010. “Accountability for Murder in the Maquiladoras: Linking Corporate Indifference to Gender Violence at the U.S.-Mexico Border.” In Making a Killing. Femicide, Free Trade, and La Frontera. Ed. A. GaSPAR DE Alba, with G. Guzmán. Austin: University of Texas Press. 25-61.

Blaut, J. 1992. “The Theory of Cultural Racism.” Antipode 24, 4: 289-299. 25 Feb. 2012. http://www.mdcbowen.org/p2/rm/theory/blaut.htm

BowdEn, C. 1996. “While you were Sleeping.” Harper's Magazine (December). http:// dieoff.org/page77.htm

Brader, T., N.A. Valentino, and Elizabeth Suhay. 2008. "What Triggers Public Opposition to Immigration? Anxiety, Group Cues, and Immigration Threat." American Journal of Political Science 52, 4 October 2008: 959-978.

Buchanan, P.J. 2006. "Will America Survive to 2050?” http://buchanan.org/blog/ pjb-will-america-survive-to-2050-57.

---. 2004. “America in 2050: Another Country." 25 Feb. 2012. http://www.wnd. com/2004/03/23870/..

Calavita, K. 1996. “The New Politics of Immigration: 'Balanced-Budget Conservatism' and the Symbolism of Proposition 187." Social Problems 23, 3: 284-305.

Canavagh, J., S. Anderson, J. Serra, and J.E. Espinosa. 2002. "Happily Ever NAFTA?" Foreign Policy 132 September-October: 58-65.

Demo, A.T. 2004. "Policy and Media in Immigration Studies." Rhetoric \& Public Affairs 7, 2 Summer: 215-229.

Dora the Explorer. 2000. Created by C. GIFFORD, V. WALSH and E. WeINER. Nickleodeon cable television network.

Duignan, P., and L.H. GAnN, eds. 1998. The Debate in the United States over Immigration. Standford, CA: Hoover Institution Press.

Durand, J., and D.S. Massey, eds. 2004. Crossing the Border. Research from the Mexican Migration Project. New York: Russell Sage Foundation.

Fisher, M. 2010. "How Dora the Explorer Explains the Immigration Debate." The Atlantic Wire. 27 Feb. 2012. http://www.theatlanticwire.com/politics/2010/05/ how-dora-the-explorer-explains-the-immigration-debate/19663/

Gaspar de Alba, A. 2005. Desert Blood. The Juárez Murders. Houston, TX: Arte Público. 
Gaspar de Alba, A., ed. 2010. Making a Killing. Femicide, Free Trade, and La Frontera. Austin: University of Texas Press.

Gerson, D. 2007. "Bordertown Premieres at Berlinale: A Filmaker's Crusade to see Justice Done.” Spiegel Online International. February 28, 2012. http://www.spiegel. de/international/bordertown-premieres-at-berlinale-a-filmmaker-s-crusade-to-seejustice-done-a-466465.html

Guidotti-Hernández, N.M. 2007. “Dora the Explorer, Constructing 'Latinidades' and the Politics of Global Citizenship.” Latino Studies 5: 209-232.

Hollinger, D.A. 2000/1995. Postethnic America. Beyond Multiculturalism. Revised and updated edition. New York: Basic Books.

Johnson, K.R. 1997. “The New Nativism. Something Old, Something New, Something Borrowed, Something Blue.” In Immigrants Out! The New Nativism and the AntiImmigrant Impulse in the United States. Ed. J.F. PEREA. New York and London: New York University Press. 165-189.

Kellner, D. 2011. "Cultural Studies, Multiculturalism, and Media Culture.” In Gender, Race, and Class in Media. A Critical Reader. $3^{\text {rd }}$ ed. Eds. G. Dines and J.M. Humez. Thousand Oaks, CA.: Sage.

Livingston, J. 2004. "Murder in Juárez: Gender, Sexual Violence, and the Global Assembly Line". Frontiers: A Journal of Women Studies 25, 1: 59-76. DOI: 10. 1353/fro.2004.0034

Maciel, D.R. and M.R. GarcíA-Acevedo. 1998. "The Celluloid Immigrant. The Narrative Films of Mexican Immigration." Culture Across Borders. Mexican Immigration \& Popular Culture. Eds. D.R. Maciel and M. Herrera-SobeK. Tucson: University of Arizona Press. 149-202.

Nava, G. 2006. Ciudad del silencio (Bordertown). Capitol Films.

Nevins, J. 2012. Operation Gatekeeper and Beyond. The War on 'Illegals'and the Remaking of the U.S.-Mexico Boundary. $2^{\text {nd }}$ ed. New York and London: Routledge.

Ono, K.A. and J.M. Sloop. 2002. Shifting Borders: Rhetoric, Immigration, and California's Proposition 187. Philadelphia: Temple University Press.

PuEnTE, T. 2010. "Is Dora the Explorer being used in the Arizona immigration debate?" ChicagoNow, May 24. Chicanísima: Latino politics, news and culture. http://www. chicagonow.com/chicanisima-latino-politics-news-and-culture/2010/05/is-dora-theexplorer-being-used-in-the-arizona-immigration-debate/

SAsSEn, S. 1989. “America's Immigration 'Problem'.” World Policy Journal 6, 4 Fall: 811-832.

---. 2002. "The Repositioning of Citizenship: Emergent Subjects and Spaces for Politics". Berkeley Journal of Sociology 46: 4-25. http://transnationalism.uchicago. edu/RepositioningCitizenship.pdf 
Sibley, D. 1995. Geographies of Exclusion. Society and Difference in the West. London and New York: Routledge.

SIMPSON, J.S. 2003. Review of Shifting Borders: Rhetoric, Immigration, and California's Proposition 187 by Kent A. Ono; John M. Sloop. Journal of American Ethnic History 22, 4 Summer: 84-86.

Schmidt Camacho, A.R. 2005. "Ciudadana X: Gender Violence and the Denationalization of Women's Rights in Ciudad Juárez, Mexico." The New Centennial Review 5, 1 Spring: 255-292. DOI: 10.1353/ncr.2005.0030

Sollors, W. Beyond Ethnicity: Consent and Descent in American Culture. 1986. New York: Oxford University Press.

SuÁRez-Orozco, M.M. 1996. “California Dreaming: Proposition 187 and the Cultural Psychology of Racial and Ethnic Exclusion.” Anthropology \& Education Quarterly 27, 2 June: 151-167.

YelLen, S. 2010. "Dora the Explorer Arrested in Arizona with Boots, Backpack and Cousin Diego." May 4. Huff Post Comedy. http://www.huffingtonpost.com/shermanyellen/dora-the-explorer-arreste_b_562492.html 